\title{
Assessment of atmospheric trace element concentrations by lichen-bag near an oil/gas pre-treatment plant in the Agri Valley (southern Italy)
}

\author{
R. Caggiano ${ }^{1}$, S. Trippetta ${ }^{1,2}$, and S. Sabia ${ }^{1}$ \\ ${ }^{1}$ IMAA, Istituto di Metodologie per l'Analisi Ambientale, CNR, C. da S. Loja, Z. I., 85050 Tito Scalo (PZ), Italy \\ ${ }^{2}$ Osservatorio Ambientale Val d'Agri, Via Vittorio Emanuele II, 3, 85052 Marsico Nuovo (PZ), Italy
}

Correspondence to: R. Caggiano (rosa.caggiano@imaa.cnr.it)

Received: 25 June 2014 - Published in Nat. Hazards Earth Syst. Sci. Discuss.: 15 October 2014

Revised: - - Accepted: 28 January 2015 - Published: 23 February 2015

\begin{abstract}
The atmospheric concentrations of 17 trace elements ( $\mathrm{Al}, \mathrm{Ca}, \mathrm{Cd}, \mathrm{Cr}, \mathrm{Cu}, \mathrm{Fe}, \mathrm{K}, \mathrm{Li}, \mathrm{Mg}, \mathrm{Mn}, \mathrm{Na}, \mathrm{Ni}, \mathrm{P}$, $\mathrm{Pb}, \mathrm{S}$, Ti and $\mathrm{Zn}$ ) were measured by means of the "lichenbag" technique in the Agri Valley (southern Italy). The lichen samples were collected from an unpolluted site located in Rifreddo forest (southern Italy), about $30 \mathrm{~km}$ away from the study area along the north direction. The bags were exposed to ambient air for 6 and 12 months. The exposedto-control (EC) ratio values highlighted that the used lichen species were suitable for biomonitoring investigations. The results showed that the concentrations of almost all the examined trace elements increased with respect to the control after 6-12-month exposures. Furthermore, $\mathrm{Ca}, \mathrm{Al}, \mathrm{Fe}, \mathrm{K}, \mathrm{Mg}$ and $\mathrm{S}$ were the most abundant trace elements both in the 6-month and 12-month-exposed samples. Moreover, principal component analysis (PCA) results highlighted that the major sources of the measured atmospheric trace elements were related both to anthropogenic contributions due to traffic, combustion processes agricultural practices, construction and quarrying activities, and to natural contributions mainly represented by the re-suspension of local soil and road dusts. In addition, the contribution both of secondary atmospheric reactions involving Centro Olio Val d'Agri (COVA) plant emissions and the African dust long-range transport were also identified.
\end{abstract}

\section{Introduction}

The growing interest aroused by atmospheric pollution is due to its impact on human health, air quality and global climate change (IPCC, 2013; Kulmatov and Hojamberdiev, 2010; Pope III and Dockery, 2006). In this field, atmospheric particles play a key role also because they may contain high concentrations of several trace elements known to have toxic effects on human health and environment.

The trace element inputs into the environment have increased mostly over the last few years (Mbenguea et al., 2014; Achotegui-Castells et al., 2013; Ny and Lee, 2011; Gao et al., 2002). These inputs are due to both natural emissions - continental dust, volcanic dust and gas, sea spray, and biogenic particles - and human activities such as industrial sources, present and former mining activities, foundries, smelters and traffic (Aničic et al., 2009; Gong and Barrie, 2005). Frequently, the anthropogenic sources are more significant than the natural ones for most of the toxic trace elements (e.g. Pb and Cd) (Caggiano et al., 2010; Mazzei et al., 2008).

The monitoring of the trace element-related atmospheric pollution is a very complex problem due to a variety of reasons: the great number of potentially dangerous substances, the difficulty in estimating bioavailability, the large spatial and temporal variations of the pollution phenomena, the high costs of the recording instruments and hence the low sampling density of a purely instrumental approach (AchoteguiCastells et al., 2013; Wolterbeek, 2002).

For this reason, innovative techniques devoted to the atmospheric trace element monitoring have been developed 
and continuously improved. Among these, the biomonitoring has become a topical method for the assessment of the trace element presence in the atmosphere. The use of lichens as biomonitors for atmospheric deposition of trace elements has been reported in a large number of studies including local investigations, as well as regional, national and international surveys in different parts of the world (e.g. Cucu-Man and Steinnes, 2013; Abdullah et al., 2012; Guttová et al., 2011; Spagnuolo et al., 2011; Baptista et al., 2008). In particular, the lichen-bag technique has been widely applied and is a well-established methodology for the assessment of the atmospheric trace element deposition. The lichen-bag technique has a lot of advantages such as well-defined exposure time, the knowledge of the original concentration of chemical elements in the used biomonitors, flexibility both in site selection and number of stations that can be chosen. Moreover, it allows repeated assay of the same element, in the same place, with identical samplers, thus achieving comparable results over time.

Since the assessment of the pollution levels is strictly connected to a detailed knowledge of the trace element concentrations and their major sources, multi-elemental surveys and advanced statistical techniques for the identification of their sources are necessary to gain insight into the characteristics of the atmospheric trace elements in order to assess the ecosystem state, establish the potential human health risks and develop effective strategies for the control of the emission sources (Charlesworth et al., 2011; Viana et al., 2008).

In the light of this, the present study deals with the characterization of the atmospheric trace element concentrations using the "lichen-bag" technique and the identification of their main emission sources. The study was performed in the Agri Valley (Basilicata region - southern Italy), an area of international concern since it houses one of the largest European on-shore reservoirs and the biggest oil/gas pretreatment plant (i.e. Centro Olio Val d'Agri - COVA) within an anthropized context (Trippetta et al., 2014). This plant produces the emissions of several pollutants that could exert a considerable impact on a widespread area.

These types of studies are of great importance especially in areas where protected habitats and valuable agricultural cultivations coexist with industrial activities and where air pollution-related data, especially biomonitoring data, are still lacking in contrast to other areas of the country (Adamo et al., 2003, 2007; Bargagli et al., 1987).

The results of this study could give an important contribution both to the development of air quality control strategies and the evaluation of the impacts of the atmospheric pollution on the ecosystem state and human health.

\section{Materials and methods}

\subsection{Study area}

The Agri Valley is located in the Basilicata region, southern Italy (Fig. 1). It is located at about $600 \mathrm{~m}$ a.s.l. and it is surrounded by mountains. Agriculture, pasture and woodland are the prevailing land uses. The climate of the studied area is that of the typical Mediterranean zone. The average values of the main meteorological parameters in the period from October 2011 to October 2012 are as follows: air temperature $13.4{ }^{\circ} \mathrm{C}$, relative humidity $68.3 \%$, atmospheric pressure $394.4 \mathrm{hPa}$, wind speed $1.9 \mathrm{~ms}^{-1}$. Dominant winds in the examined area are in the ESE and S direction. The Agri Valley gives hospitality to a wide variety of protected natural habitats and is partially situated within the Appennino Lucano - Val d'Agri - Lagonegrese National Park. In fact, about $51 \%$ of the Agri Valley area is protected. At the same time, this area is characterized by the presence of one of the largest European on-shore reservoirs (crude oil and gas) and of an oil/gas pre-treatment plant (identified as Centro Olio Val d'Agri - COVA). The minimum distance between the COVA plant and the borders of the Appennino Lucano Val d'Agri Lagonegrese National Park is about $2 \mathrm{~km}$. Moreover, the COVA plant is located in an anthropized area characterized by several small towns, from 1700 to 5400 inhabitants. The nominal treatment capacity of the COVA plant is of $16500 \mathrm{~m}^{3} \mathrm{~d}^{-1}$ of crude oil and $3100000 \mathrm{Sm}^{3} \mathrm{~d}^{-1}$ of associated gas. The COVA plant represents the anthropogenic activity with the highest release of atmospheric pollutant emissions in the Agri Valley (Trippetta et al., 2013). Moreover, it represents the most important industrial activity in the area and its presence has also produced a significant increase in the anthropogenic activities linked with the extraction of the hydrocarbons.

\subsection{Lichen-bag preparation and sample exposure}

Samples of Platismatia glauca (L.) W. L. Culb. and C. F. Culb. (foliose species), Evernia prunastri (L.) Ach., Ramalina fraxinea (L.) Ach. and Pseudevernia furfuracea (L.) Zopf (fruticose species) lichen species were collected in October 2011 at an unpolluted site located in Rifreddo forest (hereafter named control site), southern Italy $\left(40^{\circ} 33^{\prime} 53.37^{\prime \prime} \mathrm{N}, 15^{\circ} 50^{\prime} 22.34^{\prime \prime} \mathrm{E}\right.$, about $1146 \mathrm{~m}$ a.s.l.).The Rifreddo forest is about $30 \mathrm{~km}$ away from the study area along the North direction. It is a Site of Community Importance (SCI) of the Natura 2000 network and covers a surface area of nearly 520 hectares.

The lichen species chosen for the present study are easy to identify and handle in the laboratory, they also have a large specific surface area and a wide spatial and temporal distribution. They have been widely and successfully used in biomonitoring studies as lichen bags and they also occur abundantly and naturally in the Rifreddo forest. 


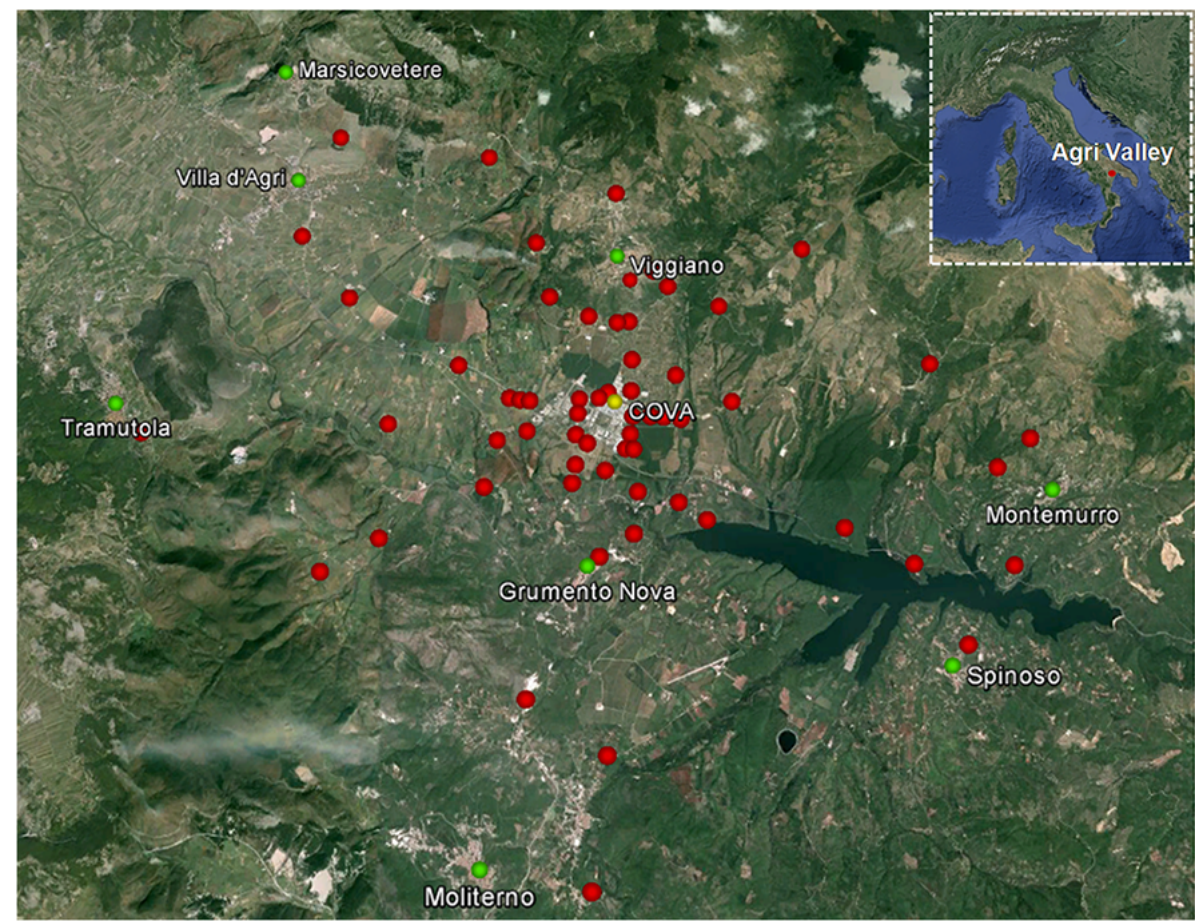

Figure 1. Location of the biomonitoring stations (red placemarks). The image also reports the location of the Centro Olio Val d'Agri (COVA) plant (yellow placemark) and of the main towns (green placemarks). Aerial photography to courtesy of Google Earth (http://earth.google. $\mathrm{com} /)$.

After the collection, the lichens were oven-dried at $30^{\circ} \mathrm{C}$ to a constant weight and carefully cleaned under binocular microscope to remove soil, bark and extraneous material (Wolterbeek and Bode, 1995). Then, the samples were homogenized by manually stirring. About $5 \mathrm{~g}$ of homogenously mixed, oven-dried ( $25 \%$ for each lichen species) material was used to prepare two bags. The bags were made of a polyethylene mesh $(2 \mathrm{~mm} \times 2 \mathrm{~mm})$ cut into pieces of approximately $12 \mathrm{~cm} \times 12 \mathrm{~cm}$ and packed loosely with a nylon rope.

The biomonitoring network consisted of 59 sites distributed around the COVA plant and covering an area of about $100 \mathrm{~km}^{2}$ also including the major towns located in the area (Fig. 1). Each sampling point was selected using Agri Valley maps and taking the landscape characteristics into account. A portable Global Positioning System (GPS) was used for providing geo-references of the on-site points. In each site, two bags were hung on tree branches at a height of about $3 \mathrm{~m}$ above the ground. The branches were carefully selected so as to expose the lichen bags freely to ambient air. Moreover, the sampling points are chosen at least at $100 \mathrm{~m}$ away from roads and buildings In order to explore the temporal variation of the trace elements, in each site one bag was collected after 6 months (from October 2011 to April 2012) and the other one after 12 months (from October 2011 to October 2012) of continuous exposures. All samples were stored in polyethylene bags until chemical analysis.

\subsection{Trace element analysis}

In order to determine the total concentration of 17 trace elements (i.e. $\mathrm{Al}, \mathrm{Ca}, \mathrm{Cd}, \mathrm{Cr}, \mathrm{Cu}, \mathrm{Fe}, \mathrm{Li}, \mathrm{K}, \mathrm{Mg}, \mathrm{Mn}, \mathrm{Na}, \mathrm{Ni}$, $\mathrm{P}, \mathrm{Pb}, \mathrm{S}$, Ti and $\mathrm{Zn}$ ), $500 \mathrm{mg}$ dry weight (dw) of lichen samples were acidic digested in a solution of $6 \mathrm{~mL} \mathrm{HNO}_{3}+1 \mathrm{~mL}$ $\mathrm{H}_{2} \mathrm{O}_{2}$ (Loppi and Frati, 2006).

Then, the samples were measured by means of inductively coupled plasma optical emission spectrometry (ICPOES) or graphite furnace atomic absorption spectrometry (GF-AAS). In particular, the total concentrations of $\mathrm{Al}, \mathrm{Ca}$, $\mathrm{Cr}, \mathrm{Fe}, \mathrm{Li}, \mathrm{K}, \mathrm{Mg}, \mathrm{Mn}, \mathrm{Na}, \mathrm{P}, \mathrm{S}$, Ti and $\mathrm{Zn}$ were measured by means of ICP-OES, while $\mathrm{Cd}, \mathrm{Cu}, \mathrm{Ni}$ and $\mathrm{Pb}$ total concentrations were determined by means of GF-AAS. The blank (reagent + beaker) contribution was evaluated, and the resulting values were subtracted from the ICP-OES or GF-AAS measurements of real samples. For all the elements blanks were found to be $<10 \%$ of the measured values.

The method detection limit (MDL) was used to determine the lowest concentration level that could be detected, statistically different from a blank. To this aim, 10 blanks were prepared and analyzed and MDLs were determined by adding 3 standard deviations of the blank readings to the average blank values (Yatkin and Bayram, 2007). The results obtained are reported in Table 1. Moreover, the validity of the whole analytical procedure was checked by using the International Atomic Energy Agency (IAEA) standard reference 
Table 1. Experimental values (mean value \pm standard deviation) and certified values are referred to the International Atomic Energy Agency (IAEA) standard reference material, IAEA 336. Recovery percentage and method detection limit (MDL) results are also reported.

\begin{tabular}{lllcc}
\hline Element & $\begin{array}{l}\text { Experimental } \\
\text { value } \\
\left(\mathrm{mg} \mathrm{kg}^{-1}\right)\end{array}$ & $\begin{array}{l}\text { Certified } \\
\text { value } \\
\left(\mathrm{mg} \mathrm{kg}^{-1}\right)\end{array}$ & $\begin{array}{c}\text { Recovery } \\
(\%)\end{array}$ & $\begin{array}{l}\text { MDL } \\
(\mathrm{ppm})\end{array}$ \\
\hline $\mathrm{Al}^{\mathrm{a}}$ & $482 \pm 71$ & 680 & 71 & 0.04665 \\
$\mathrm{Ca}^{\mathrm{a}}$ & - & not reported & - & 0.20283 \\
$\mathrm{Cd}^{\mathrm{b}}$ & $0.155 \pm 0.12$ & 0.117 & 133 & 0.00152 \\
$\mathrm{Cr}^{\mathrm{a}}$ & $1.265 \pm 0.20$ & 1.060 & 119 & 0.00324 \\
$\mathrm{Cu}^{\mathrm{b}}$ & $4.952 \pm 1.16$ & 3.600 & 138 & 0.00865 \\
$\mathrm{Fe}^{\mathrm{a}}$ & $361 \pm 6$ & 430 & 84 & 0.13140 \\
$\mathrm{~K}^{\mathrm{a}}$ & $1734 \pm 41$ & 1840 & 94 & 0.00867 \\
$\mathrm{Li}^{\mathrm{a}}$ & - & not reported & - & 0.00006 \\
$\mathrm{Mg}^{\mathrm{a}}$ & - & not reported & - & 0.00423 \\
$\mathrm{Mn}^{\mathrm{a}}$ & $48 \pm 2$ & 63 & 76 & 0.06187 \\
$\mathrm{Na}^{\mathrm{a}}$ & $310 \pm 24$ & 320 & 97 & 0.03230 \\
$\mathrm{Ni}^{\mathrm{a}}$ & - & not reported & - & 0.00354 \\
$\mathrm{P}^{\mathrm{a}}$ & $522 \pm 27$ & 610 & 86 & 0.00415 \\
$\mathrm{~S}^{\mathrm{a}}$ & - & not reported & - & 8.16875 \\
$\mathrm{~Pb}^{\mathrm{b}}$ & $4.919 \pm 0.98$ & 4.900 & 105 & 0.08070 \\
$\mathrm{Ti}^{\mathrm{a}}$ & - & not reported & - & 0.01488 \\
$\mathrm{Zn}^{\mathrm{a}}$ & $31 \pm 3$ & 30.4 & 103 & 0.00282 \\
\hline
\end{tabular}

${ }^{\mathrm{a}}$ ICP-OES and ${ }^{\mathrm{b}}$ GF-AAS.

material, IAEA 336. The obtained values were in good agreement with the certified values (Table 1).

\subsection{Data analysis}

In order to identify the main trace element sources, the principal component analysis (PCA) was used. PCA is a multivariate statistical technique widely applied both to the study of the correlation structure between the different atmospheric pollutants and the identification of the source types which can give rise to their presence in the atmosphere (Yatkin and Bayram, 2007; Quiterio et al., 2004; Vallius et al., 2003; Dìaz et al., 2002). In this study, each variable was normalized to unit variance, and all the principal factors with eigenvalues $>0.8$ were retained. To clarify the meaning of the principal components $\left(\mathrm{PC}_{\mathrm{s}}\right)$, the retained factors were subsequently subject to the varimax normalized rotation.

SPSS $^{\odot}$ for Windows version 12.0 was used for the multivariate statistical analysis.

\section{Results and discussion}

\subsection{Exposed to control ratio}

The ratio of the concentrations of each trace elements in exposed samples with respect to control samples (i.e. "exposed to control ratio" - EC ratio) was used for calculating the ac-
Table 2. Scale for the interpretation of the exposed to control (EC) ratios (Frati et al., 2005).

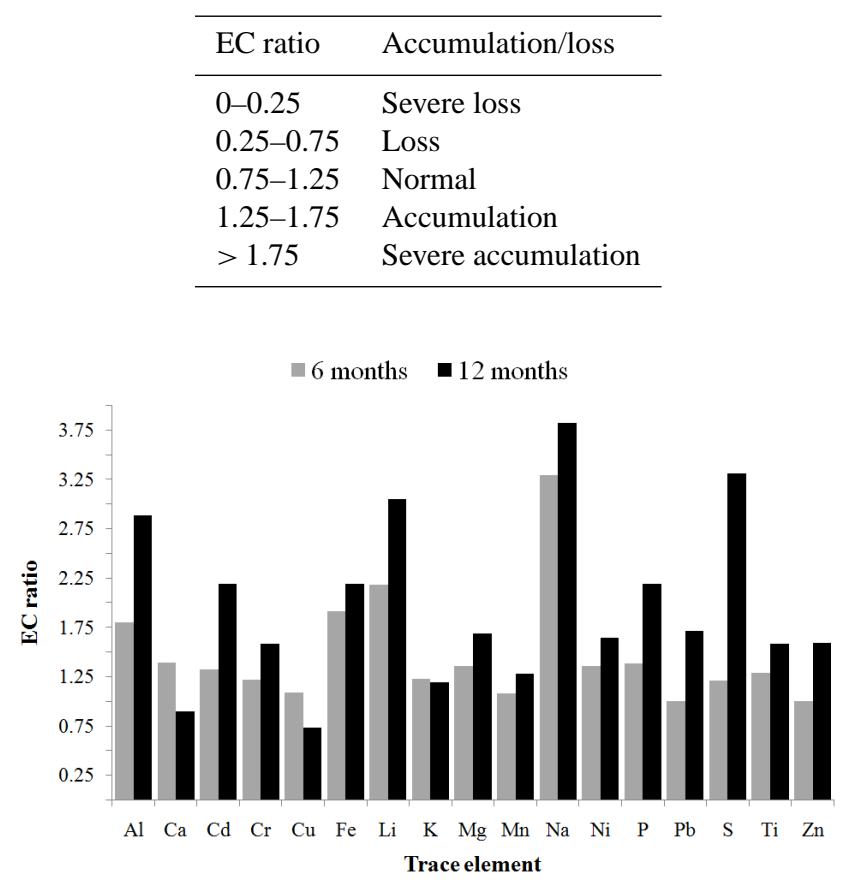

Figure 2. Exposed to control (EC) ratios calculated for the trace element concentrations measured in lichen samples after 6- and 12month exposures.

cumulation rates in the lichen bags. According to Frati et al. (2005), a five-class interpretative scale based on the deviation of the $\mathrm{EC}$ ratio from the control condition, assumed to be $\pm 25 \%$ from the ratio of 1 , was used (Table 2).

By analyzing the mean values of the EC ratios calculated for each trace element after 6- and 12-month exposures (Fig. 2), it can be observed that there were no cases of "severe loss" $(0<\mathrm{EC}<0.25)$ and only one case of "loss" $(0.25<\mathrm{EC}<0.75)$ occurred. Moreover, the "normal" condition $(0.75<\mathrm{EC}<1.25)$ was observed for 9 times. Finally, the "accumulation" $(1.25<\mathrm{EC}<1.75)$ and "severe accumulation" $(\mathrm{EC}>1.75)$ conditions were observed for 13 and 11 times, respectively.

Focusing on the single trace element, severe accumulation was observed for $\mathrm{Al}, \mathrm{Fe}, \mathrm{Li}, \mathrm{Na}$ after both 6- and 12-month exposures and for $\mathrm{Cd}, \mathrm{P}$ and $\mathrm{S}$ after a 12-month exposure. A significant increase was observed for $\mathrm{Mg}, \mathrm{Ni}$ and $\mathrm{Ti}$ whose EC values fell within the "accumulation" class after both 6and 12-month exposures. An increase in the EC values was also recorded for $\mathrm{Ca}$ and $\mathrm{P}$ after a 6-month exposure and for $\mathrm{Cr}, \mathrm{Pb}, \mathrm{Mn}$ and $\mathrm{Zn}$ after a 12-month exposure. In fact, all these elements fell within the "accumulation" class.

Regarding $\mathrm{Cr}, \mathrm{Cu}, \mathrm{Pb}, \mathrm{S}$ and $\mathrm{Zn}$, they showed a moderate change with EC values falling within the "normal" class after a 6-month exposure, while $\mathrm{K}$ and $\mathrm{Mn}$ fell in the "normal" class for both the exposure periods. Finally, a decrease was 
observed for $\mathrm{Ca}$ and $\mathrm{Cu}$ only after a 12-month exposure. A loss of $\mathrm{Cu}$ and/or $\mathrm{Ca}$ after a long period of exposure has also been observed in literature (Culicov and Yurukova, 2006; Yurukova and Ganeva, 1997).

Therefore, the results highlight that the accumulation capacity of the lichens in relation to the analyzed trace elements is different but that the combination of the used lichen species are suitable for the biomonitoring investigation.

\subsection{Trace elements after 6-12-month exposures}

The mean concentration values of the 17 trace elements analyzed in the lichen bags after 6- and 12-month exposures in 59 selected monitoring sites located in the Agri Valley and the concentration values measured at the control site are presented in Table 3.

As Table 3 shows, $\mathrm{Al}, \mathrm{Ca}, \mathrm{Fe}, \mathrm{K}, \mathrm{Mg}$ and $\mathrm{S}$ were the most abundant elements both in the 6- and 12-month-exposed samples.

By comparing the mean values of the trace element concentrations measured in the lichen samples after 6-month exposures with those measured in the control ones, it can be seen that the major increase was observed for $\mathrm{Na}(229 \%), \mathrm{Li}$ $(116 \%), \mathrm{Fe}(91 \%)$ and $\mathrm{Al}(80 \%)$. An increase was also observed for 9 trace elements: P (40\%), Ca (39\%), Ni (36\%), $\mathrm{Mg}(35 \%), \mathrm{Cd}(32 \%), \mathrm{Ti}(29 \%), \mathrm{K}(23 \%), \mathrm{Cr}(22 \%)$ and $\mathrm{S}$ (21\%). Finally, no significant increase (less than $10 \%$ ) was recorded for the remaining elements.

By focusing on the comparison between the trace element concentrations measured in 12-month-exposed samples and in the control samples, it can be seen an increase of 282, 231, 203, 189, 119 and $118 \%$ for $\mathrm{Na}, \mathrm{S}, \mathrm{Li}, \mathrm{Al}, \mathrm{Fe}$ and $\mathrm{P}$, and $\mathrm{Cd}$, respectively. An increase was also observed for $\mathrm{Mg}(69 \%)$, $\mathrm{Pb}(68 \%)$, Ni (65\%), Ti (61\%), Zn (59\%), Cr (58\%), Mn $(28 \%)$ and $\mathrm{K}(20 \%)$. Finally, $\mathrm{Ca}$ and $\mathrm{Cu}$ were the only two elements showing a decrease in their concentrations after a 12-month exposure.

Regarding the difference in concentrations as a function of the time of exposure, the results pointed out an increase of almost all the trace element concentrations during longer exposure periods. Particularly, the S concentration measured in samples exposed for 12 months was higher than the $\mathrm{S}$ concentration measured in the samples exposed for 6 months with an increase by $174 \%$ (from 1265 to $3466 \mathrm{mg} \mathrm{kg}^{-1}$ ). The results also highlight an increase in $\mathrm{Cd}(64 \%), \mathrm{Pb}(63 \%)$, $\mathrm{Al}(60 \%), \mathrm{Zn}(58 \%)$ and $\mathrm{P}(57 \%)$ concentrations after a 12 month exposure. As for $\mathrm{Fe}, \mathrm{Mg}, \mathrm{Mn}, \mathrm{Na}, \mathrm{Ni}$, and $\mathrm{Ti}$, the mean concentration values measured in the samples exposed for 12 months showed a percentage increases ranging between 14 and $25 \%$ with respect to the 6-month-exposed samples. No difference was found in $\mathrm{K}$ concentrations between samples measured after 6 and 12 months of exposure. Finally, a decrease in the $\mathrm{Ca}$ and $\mathrm{Cu}$ concentrations (36 and $33 \%$, respectively) was observed with the increase in the exposure time.
Table 3. Mean value \pm standard deviation $(m \pm$ SD) of the trace element concentrations measured in the control sample and in lichen bags after 6- and 12-month exposures. The mean values of the trace element concentrations are highlighted in bold.

\begin{tabular}{llll}
\hline $\begin{array}{l}\text { Trace } \\
\text { element }\end{array}$ & $\begin{array}{l}\text { Control } \\
\text { sample } \\
{\left[\mathrm{mg} \mathrm{kg}^{-1}\right]}\end{array}$ & $\begin{array}{l}\text { 6-month } \\
\text { exposure } \\
{\left[\mathrm{mg} \mathrm{kg}^{-1}\right]}\end{array}$ & $\begin{array}{l}\text { 12-month } \\
\text { exposure } \\
{\left[\mathrm{mg} \mathrm{kg}^{-1}\right]}\end{array}$ \\
\hline $\mathrm{Al}$ & $\mathbf{7 7 0} \pm 110$ & $\mathbf{1 3 8 5} \pm 370$ & $\mathbf{2 2 2 3} \pm 639$ \\
$\mathrm{Ca}$ & $\mathbf{1 0 6 6 5} \pm 928$ & $\mathbf{1 4 8 6 7} \pm 2274$ & $\mathbf{9 5 8 9} \pm 1021$ \\
$\mathrm{Cd}$ & $\mathbf{0 . 5} \pm 0.1$ & $\mathbf{0 . 7} \pm 0.4$ & $\mathbf{1 . 1} \pm 0.5$ \\
$\mathrm{Cr}$ & $\mathbf{1 . 7} \pm 0.3$ & $\mathbf{2 . 1} \pm 0.6$ & $\mathbf{2 . 7} \pm 0.7$ \\
$\mathrm{Cu}$ & $\mathbf{9} \pm 3$ & $\mathbf{1 0} \pm 2$ & $\mathbf{7} \pm 1$ \\
$\mathrm{Fe}$ & $\mathbf{6 0 9} \pm 87$ & $\mathbf{1 1 6 5} \pm 325$ & $\mathbf{1 3 3 3} \pm 390$ \\
$\mathrm{~K}$ & $\mathbf{2 7 8 5} \pm 393$ & $\mathbf{3 4 2 6} \pm 697$ & $\mathbf{3 3 3 6} \pm 1023$ \\
$\mathrm{Li}$ & $\mathbf{0 . 6} \pm 0.1$ & $\mathbf{1 . 3} \pm 0.4$ & $\mathbf{1 . 9} \pm 0.5$ \\
$\mathrm{Mg}$ & $\mathbf{1 0 4 6} \pm 102$ & $\mathbf{1 4 1 7} \pm 174$ & $\mathbf{1 7 6 8} \pm 335$ \\
$\mathrm{Mn}$ & $\mathbf{1 0 0} \pm 21$ & $\mathbf{1 0 8} \pm 36$ & $\mathbf{1 2 8} \pm 39$ \\
$\mathrm{Na}$ & $\mathbf{1 9 0} \pm 42$ & $\mathbf{6 2 6} \pm 376$ & $\mathbf{7 2 7} \pm 191$ \\
$\mathrm{Ni}$ & $\mathbf{0 . 7} \pm 0.2$ & $\mathbf{1 . 0} \pm 0.3$ & $\mathbf{1 . 2} \pm 0.3$ \\
$\mathrm{P}$ & $\mathbf{6 7} \pm 4$ & $\mathbf{9 3} \pm 16$ & $\mathbf{1 4 7} \pm 33$ \\
$\mathrm{~Pb}$ & $\mathbf{7} \pm 2$ & $\mathbf{7} \pm 4$ & $\mathbf{1 2} \pm 9$ \\
$\mathrm{~S}$ & $\mathbf{1 0 4 6} \pm 331$ & $\mathbf{1 2 6 5} \pm 361$ & $\mathbf{3 4 6 6} \pm 606$ \\
$\mathrm{Ti}$ & $\mathbf{2 4} \pm 7$ & $\mathbf{3 1} \pm 8$ & $\mathbf{3 8} \pm 10$ \\
$\mathrm{Zn}$ & $\mathbf{4 7} \pm 11$ & $\mathbf{4 7} \pm 22$ & $\mathbf{7 5} \pm 31$ \\
\hline & & &
\end{tabular}

In order to gain a better understanding of the correlation structure between the trace elements in lichen samples, the Pearson's correlation coefficients $(\rho)$ were calculated between the trace element concentrations measured in the lichens samples after a 6-month exposure and between the trace element concentrations measured in the lichens samples after a 12-month exposure.

Significant positive correlations $(\rho>0.70)$ were found between elements generally considered of natural origin, i.e. Al-Fe, $\mathrm{Li}-\mathrm{Al}, \mathrm{Ti}-\mathrm{Al}$ and Ti-Fe after a 6-month exposure and between $\mathrm{Al}-\mathrm{Li}, \mathrm{Li}-\mathrm{Fe}$ and $\mathrm{Ti}-\mathrm{Al}$ after a 12-month exposure. Significant correlations were also found between elements of anthropic origin i.e. $\mathrm{Cr}-\mathrm{Cu}, \mathrm{Li}-\mathrm{Fe}, \mathrm{Ni}-\mathrm{Cu}, \mathrm{Pb}-\mathrm{Cr}$ and $\mathrm{Zn}-\mathrm{Pb}$ in the samples exposed for 6-months and between $\mathrm{Cd}$ $\mathrm{Cr}, \mathrm{Ni}-\mathrm{Cd}, \mathrm{Pb}-\mathrm{Cd}, \mathrm{Zn}-\mathrm{Cd}$ after a 12 -month exposure. Moreover, the results also showed a correlation between elements of different origin such as $\mathrm{Al}-\mathrm{Cr}$ and $\mathrm{Fe}-\mathrm{Cr}$.

\subsection{Principal component analysis (PCA)}

By applying the PCA to the concentrations of the trace elements measured in the lichen samples after a 6-month exposure, five significant components $\left(\mathrm{PC}_{\mathrm{s}-6}\right.$ months $)$ were obtained (Table 4a).

As reported in Table 4a, $\mathrm{PC}_{1-6}$ months is characterized by high loadings of $\mathrm{Al}, \mathrm{Ti}, \mathrm{Fe}, \mathrm{Li}$ and $\mathrm{Cr}$. $\mathrm{Al}$, Ti and $\mathrm{Fe}$ are chemical elements typically used as tracers for soil dust and/or crustal re-suspension (Pant and Harrison, 2012). Regarding $\mathrm{Li}$ and $\mathrm{Cr}$, they are found in vehicle exhausts, diesel vehicle 
Table 4. PCA results after the normalized varimax rotation for trace element concentrations measured in lichen samples after (a) 6-month and (b) 12-month exposures. Loadings and percentage of explained variance $(P \%)$ are reported.

\begin{tabular}{|c|c|c|c|c|c|c|c|c|c|}
\hline \multirow{2}{*}{\multicolumn{2}{|c|}{$\begin{array}{c}\mathrm{PC}_{1-6 \text { months }} \\
P \%=30\end{array}$}} & \multirow{2}{*}{\multicolumn{2}{|c|}{$\begin{array}{c}\mathrm{PC}_{2-6} \text { months } \\
P \%=22\end{array}$}} & \multirow{2}{*}{\multicolumn{2}{|c|}{$\begin{array}{c}\mathrm{PC}_{3-6 \text { months }} \\
P \%=12\end{array}$}} & \multirow{2}{*}{\multicolumn{2}{|c|}{$\begin{array}{c}\mathrm{PC}_{4-6} \text { months } \\
P \%=9\end{array}$}} & \multirow{2}{*}{\multicolumn{2}{|c|}{$\begin{array}{c}\mathrm{PC}_{5-6} \text { month } \\
P \%=9\end{array}$}} \\
\hline & & & & & & & & & \\
\hline $\mathrm{Al}$ & 0.97 & $\mathrm{Zn}$ & 0.92 & $\mathrm{P}$ & 0.80 & $\mathrm{Na}$ & 0.85 & $\mathrm{Ca}$ & 0.88 \\
\hline $\mathrm{Ti}$ & 0.97 & $\mathrm{Cd}$ & 0.91 & $\mathrm{Mn}$ & 0.72 & $\mathrm{~S}$ & 0.65 & $\mathrm{Mg}$ & 0.58 \\
\hline $\mathrm{Fe}$ & 0.96 & $\mathrm{~Pb}$ & 0.91 & $\mathrm{~K}$ & 0.67 & & & & \\
\hline $\mathrm{Li}$ & 0.88 & $\mathrm{Cu}$ & 0.68 & & & & & & \\
\hline $\mathrm{Cr}$ & 0.84 & $\mathrm{Ni}$ & 0.53 & & & & & & \\
\hline
\end{tabular}

\begin{tabular}{|c|c|c|c|c|c|c|c|c|c|}
\hline \multicolumn{10}{|c|}{ (b) } \\
\hline \multicolumn{2}{|c|}{$\mathrm{PC}_{1-12 \text { months }}$} & \multicolumn{2}{|c|}{$\mathrm{PC}_{2-12}$ months } & \multicolumn{2}{|c|}{$\mathrm{PC}_{3-12}$ months } & \multicolumn{2}{|c|}{$\mathrm{PC}_{4-12}$ months } & \multicolumn{2}{|c|}{$\mathrm{PC}_{5-12 \mathrm{month}}$} \\
\hline \multicolumn{2}{|c|}{$P \%=31$} & \multicolumn{2}{|c|}{$P \%=19$} & \multicolumn{2}{|c|}{$P \%=17$} & \multicolumn{2}{|c|}{$P \%=8$} & \multicolumn{2}{|c|}{$P \%=7$} \\
\hline $\mathrm{Al}$ & 0.97 & $\mathrm{Cd}$ & 0.90 & $\mathrm{P}$ & 0.82 & $\mathrm{Na}$ & 0.91 & $\mathrm{Mg}$ & 0.83 \\
\hline $\mathrm{Li}$ & 0.95 & $\mathrm{Ca}$ & 0.81 & K & 0.73 & $\mathrm{~S}$ & 0.41 & $\mathrm{Mn}$ & 0.53 \\
\hline $\mathrm{Fe}$ & 0.94 & $\mathrm{~Pb}$ & 0.75 & $\mathrm{Cu}$ & 0.69 & & & & \\
\hline $\mathrm{Cr}$ & 0.92 & $\mathrm{Zn}$ & 0.66 & $\mathrm{Zn}$ & 0.65 & & & & \\
\hline $\mathrm{Ti}$ & 0.77 & $S$ & 0.49 & $\mathrm{~S}$ & 0.43 & & & & \\
\hline $\mathrm{Ni}$ & 0.71 & & & & & & & & \\
\hline
\end{tabular}

engines and coal fly ash (Chandra Mouli et al., 2006; Wang et al., 2003). Therefore, $\mathrm{PC}_{1-6}$ months can be related to contributions of natural origin associated with those coming from traffic and coal combustion processes.

$\mathrm{PC}_{2-6}$ months is characterized by $\mathrm{Zn}, \mathrm{Cd}, \mathrm{Pb}, \mathrm{Cu}$ and Ni. These elements are generally related to anthropogenic sources represented by motor vehicle emissions, wear and tear of brake linings and other vehicle metallic parts. Therefore, this component could be associated to the contribution of anthropogenic sources identified as traffic.

$\mathrm{PC}_{3-6}$ months is related to $\mathrm{P}, \mathrm{Mn}$ and $\mathrm{K}$. As for $\mathrm{P}$, its presence in the local atmosphere could be due to the resuspension of soil particles containing naturally occurring and fertilizer-derived $\mathrm{P}$, primary biogenic aerosols and combustion sources (fossil fuel, biomass burning, biofuels) (Lettino and Fiore, 2013; Mahowald et al., 2008). As far as Mn is concerned, it is an element widely distributed in the Earth's crust and it is considered to be the twelfth most abundant element and the fifth most abundant metal (WHO, 2001). Mn enters the atmosphere through several processes which include soil erosion by winds and the re-suspension both of road dusts by vehicles and soils as a consequence of farming, construction and quarrying activities. Finally, K usually occurs in coarse particles coming from soil, but fine particles of potassium also result from wood combustion (Calvo et al., 2011; Khare et al., 2008; Zunckel et al., 2003). Therefore, this component should be related both to natural contributions mainly represented by the re-suspension of local soil as well as road dusts and anthropogenic emissions deriving from combustion processes (wood and fossil fuels), agricultural practices and construction and quarrying activities.

Regarding $\mathrm{PC}_{4-6}$ months, it is related to $\mathrm{Na}$ and $\mathrm{S}$. Sodium sulphates may form through reactions between $\mathrm{Na}^{+}$and $\mathrm{H}_{2} \mathrm{SO}_{4}$. In particular, S-rich compounds mainly emitted from the COVA plant very likely condense onto or react with pre-existing Na-rich particles that act as condensation nuclei. Moreover, Aden and Buseck (1979) observed significant $\mathrm{Na}_{2} \mathrm{SO}_{4}$ quantities in emissions from combustion processes. Therefore, this component may be related to secondary atmospheric reactions involving COVA plant emissions.

Finally, $\mathrm{PC}_{5-6}$ months is related to $\mathrm{Ca}$ and $\mathrm{Mg}$. Since the local soil is mainly composed of marls and dolomite limestone (Lettino and Fiore, 2013) including $\mathrm{Mg}$ and $\mathrm{Ca}$ in their composition, this component should be related to the contribution of local soil re-suspension.

By applying PCA to the concentrations of the trace elements measured in the lichen samples taken after 12 months of continuous exposure, five significant components were pointed out (Table 4b).

The results highlight that $\mathrm{PC}_{1-12}$ months is characterized by the same elements found in $\mathrm{PC}_{1-6}$ months such as $\mathrm{Al}, \mathrm{Li}, \mathrm{Fe}$, $\mathrm{Cr}$ and $\mathrm{Ti}$, but it is also characterized by the occurrence of $\mathrm{Ni}$. The origin of this last element, especially in the same component as $\mathrm{Cr}$, may be related to industrial emissions (Bari et al., 2009; Mazzei et al., 2008; Negral et al., 2008). Therefore, $\mathrm{PC}_{1-12}$ months identifies contributions of natural sources associated with those coming from traffic and coal combustion processes. 
As to $\mathrm{PC}_{2-12}$ months, $\mathrm{PC}_{3-12}$ months and $\mathrm{PC}_{4-12}$ months, the results point out that $\mathrm{S}$ is present in all the three components.

In particular, $\mathrm{PC}_{2-12}$ months is related both to $\mathrm{Cd}, \mathrm{Ca}, \mathrm{Pb}$ and $\mathrm{Zn}$ - trace elements typically related to traffic emissions and already found in $\mathrm{PC}_{2}-6$ months - and $\mathrm{Ca}$ and $\mathrm{S}$. As regards $\mathrm{Ca}$, when it is associated with traffic tracers, it is one of the potential markers of re-suspended road dust, but its association with $\mathrm{S}$ could also be indicative both of secondary atmospheric reactions of sulfur gaseous compounds such as those emitted from the COVA plant and particles coming from the local soil (Lettino and Fiore, 2013). Finally, calcium sulphates (mainly formed as gypsum) may also be related to the long-range transport of African dust (Dall'Osto et al., 2010), which occurs very frequently in the Mediterranean countries during the summer season (e.g. Pey et al., 2013; Boselli et al., 2012; Mona et al., 2006). Therefore, $\mathrm{PC}_{2-12}$ months identifies traffic-related contributions and secondary atmospheric reactions involving COVA plant emissions and local soil particles with a possible minor contribution of natural emissions from long-range transport of African dust.

Regarding $\mathrm{PC}_{3-12}$ months, it is characterized by $\mathrm{P}, \mathrm{K}, \mathrm{Cu}$, $\mathrm{Zn}$ and $\mathrm{S}$. The presence of $\mathrm{Cu}, \mathrm{K}, \mathrm{P}$, and $\mathrm{S}$ in the same component could suggest the influence of emissions deriving from agricultural practices. In fact, all these elements are found in fertilizers. Moreover, the copper sulphate is commonly used in grape farming, so its presence in the local atmosphere could be related to several vineyards, which characterize the area under study. Finally, K, P and Zn could also be associated to the contribution of combustion processes such as biomass burning, wood burning and forest fires, which occur very frequently during the warm season. Therefore, this component identifies the contribution of anthropogenic sources such as agricultural practice-related emissions and biomass and wood burning.

The fourth component (i.e. $\mathrm{PC}_{4-12}$ months) is related to $\mathrm{Na}$ and $\mathrm{S}$. By comparing this component with $\mathrm{PC}_{4-6}$ months, it can be observed that they are characterized by the same elements. Therefore this component keeps being essentially related to secondary atmospheric reactions involving the COVA plant emissions.

Finally, the fifth component (i.e. $\mathrm{PC}_{5-12}$ months) is characterized by $\mathrm{Mn}$ and $\mathrm{Mg}$. The origin of these elements is mainly related to local soil; therefore, this component identifies natural contributions deriving from the re-suspension of particles originating from the local soil.

\section{Conclusions}

The study presented highlights that the accumulation capacity of the lichens in relation to the analyzed trace elements is different and that the used lichen species are suitable for biomonitoring investigations. The application of PCA to the trace element concentrations measured in the lichen samples after 6- and 12-month exposures points out that an- thropogenic emissions deriving from traffic, combustion processes (wood and fossil fuels), agricultural practices, construction activities, quarrying activities, and natural emissions mainly related to the re-suspension of local soil and road dusts represent the main sources contributing to the presence of the trace elements in the local atmosphere. Furthermore, the contribution of secondary atmospheric reactions involving COVA plant emissions was also highlighted. Finally, a possible contribution of natural emissions related to African dust long-range transport was observed when the trace elements measured in the samples exposed for 12 months were considered. All this is consistent with the natural and anthropic features of the study area and also highlights a contribution due to the COVA plant and a seasonal contribution mainly related to the warm season such as longrange transport of African dust, biomass burning, wood burning and forest fires.

Acknowledgements. This work was carried out in the framework of the research agreement between "Regione Basilicata - Osservatorio Ambientale della Val d'Agri" and "Istituto di Metodologie per l'Analisi Ambientale" of the National Research Council (CNR).

Edited by: V. Lapenna

Reviewed by: three anonymous referees

\section{References}

Abdullah, M. Z. B., Saat, A. B., and Hamzah, Z. B.: Assessment of the impact of petroleum and petrochemical industries to the surrounding areas in Malaysia using mosses as bioindicator supported by multivariate analysis, Environ. Monit. Assess., 184, 3959-3969, 2012.

Achotegui-Castells, A., Sardans, J., Ribas, À., and Peñuelas, J.: Identifying the origin of atmospheric inputs of trace elements in the Prades Mountains (Catalonia) with bryophytes, lichens, and soil monitoring, Environ. Monit. Assess., 185, 615-629, 2013.

Adamo, P., Giordano, S., Vingiani, S., Castaldo Cobianchi, R., and Violante, P.: Trace element accumulation by moss and lichen exposed in bags in the city of Naples (Italy), Environ. Pollut., 122, 91-103, 2003.

Adamo, P., Giordano, S., Minganti, V., Modenesi, P., Monaci, F., Pittao, E., Tretiach, M., and Bargagli, R.: Lichen and moss bags as monitoring devices in urban areas, Part II: trace elements content in living and dead biomonitors and comparison with synthetic materials, Environ. Pollut., 146, 392-399, 2007.

Aden, G. D., and Buseck, P. R.: Rapid quantitative analysis of individual particles by energy-dispersive spectrometry, in: Proceedings of the 14th Annual Conference, edited by: Newbury, D. E., Microbeam Analysis Society, San Antonio, Texas, San Francisco Press, San Francisco, 254-258, 1979.

Aničic, M., Tasić, M., Frontasyeva, M. V., Tomašević, M., Rajšić, S., Strelkova, L. P., Popović, A., and Steinnes, E.: Active biomonitoring with wet and dry moss: a case study in an urban area, Environ. Chem. Lett., 7, 55-60, 2009. 
Baptista, M. S., Vasconcelos, M. T., Cabral, J. P., Freitas, M. C., and Pacheco, A. M.: Copper, nickel and lead in lichen and tree bark transplants over different periods of time, Environ. Pollut., 151, 408-413, 2008.

Bargagli, R., Iosco, F. P., and D'Amato, M.: Lichen biomonitoring of metals in the San Rossore Park: Contrast with previous pine needle data, Environ. Monit. Assess., 9, 285-294, 1987.

Bari, M. A., Baumbach, G., Kuch, B., and Scheffknecht, G.: Wood smoke as a source of particle-phase organic compounds in residential areas, Atmos. Environ., 43, 4722-4732, 2009.

Boselli, A., Caggiano, R., Cornacchia, C., Madonna, F., Mona, L., Macchiato, M., Pappalardo, G., and Trippetta, S.: Multi year sunphotometer measurements for aerosol characterization in a Central Mediterranean site, Atmos. Res., 104-105, 98-110, 2012.

Caggiano, R., Macchiato, M., and Trippetta, S.: Levels, chemical composition and sources of fine aerosol particles $\left(\mathrm{PM}_{1}\right)$ in an area of the Mediterranean basin, Sci. Total Environ., 408, 884895, 2010.

Calvo, A. I., Castro, A., Pont, V., Cuetos, M. J., Sánchez, M. E., and Fraile, R.: Aerosol size distribution and gaseous products from the oven-controlled combustion of straw materials, Aerosol Air Qual. Res., 11, 616-629, 2011.

Chandra Mouli, K. V. V., Venkata Subbaiah, K., and Acharyulu, S.G.: Optimal production planning under resource constraints, J. Sci. Ind. Res., 65, 966-969, 2006.

Charlesworth, S., De Miguel, E., and Ordonez, A.: A review of the distribution of particulate trace elements in urban terrestrial environments and its application to considerations of risk, Environ. Geochem. Health, 33, 103-123, 2011.

Cucu-Man, S. and Steinnes, S.: Analysis of selected biomonitors to evaluate the suitability for their complementary use in monitoring trace element atmospheric deposition, Environ. Monit. Assess., 185, 7775-7791, 2013.

Culicov, O. A. and Yurukova, L.: Comparison of element accumulation of different moss and lichen-bags, exposed in the city of Sofia (Bulgaria), J. Atmos. Chem., 55, 1-12, 2006.

Dall'Osto, M., Harrison, R. M., Highwood, E. J., O’Dowd, C., Ceburnis, D., Querol, X., and Achterberg, E. P.: Variation of the mixing state of Saharan dust particles with atmospheric transport, Atmos. Environ., 44, 3135-3146, 2010.

Dìaz, R. V., Aldape, J., and Flores, M.: Identification of airborne particulate sources, of samples collected in Ticomán, Mexico, using PIXE and multivariate analysis, Nucl. Instrum. Meth. B, 189, 249-253, 2002.

Frati, L., Brunialti, G., and Loppi, S.: Problems related to lichen transplants to monitor trace element deposition in repeated surveys: a case study from central Italy, J. Atmos. Chem., 52, 221230, 2005.

Gao, Y., Nelson, E. D., Field, M. P., Ding, Q., Li, H., Sherrell, R. M., Gigliotti, C. L., Van Ry, D. A., Glenn, T. R., and Eisenreich, S. J.: Characterization of atmospheric trace elements on $\mathrm{PM}_{2.5}$ particulate matter over the New York-New Jersey harbor estuary, Atmos. Environ., 36, 1077-1086, 2002.

Gong, S. L. and Barrie, L. A.: Trends of heavy metal components in the Arctic aerosols and their relationship to the emissions in the Northern Hemisphere, Sci. Total Environ., 342, 175-183, 2005.

Guttová, A., Lackovicová, A., Pišút, I., and Pišút, P.: Decrease in air pollution load in urban environment of Bratislava (Slovakia) in- ferred from accumulation of metal elements in lichens, Environ. Monit. Assess., 182, 361-373, 2011.

IPCC: Summary for Policymakers, in: Climate Change 2013: The Physical Science Basis, Contribution of Working Group I to the Fifth Assessment Report of the Intergovernmental Panel on Climate Change, edited by: Stocker, T. F., Qin, D., Plattner, G.-K., Tignor, M., Allen, S. K., Boschung, J., Nauels, A., Xia, Y., Bex, V., and Midgley, P. M., Cambridge University Press, Cambridge, UK and New York, NY, USA, 1535 pp., 2013.

Khare, S. P., Wall, T. F., Farida, A. Z., Liu, Y., Moghtaderi, B., and Gupta, R. P.: Factor influencing the ignition of flames from airfired swirl pf burners retrofitted to oxy-fuel, Fuel, 87, 1042-1049, 2008.

Kulmatov, R. and Hojamberdiev, M.: Distribution of heavy metals in atmospheric air of the arid zones in Central Asia, Air Qual. Atmos. Health, 3, 183-194, 2010.

Lettino, A. and Fiore, S.: Provenance of inorganic aerosol using single-particle analysis: a case study, Sci. Total Environ., 463464, 404-413, 2013.

Loppi, S. and Frati, L.: Lichen diversity and lichen transplants as monitors of air pollution in a rural area of central Italy, Environ. Monit. Assess., 114, 361-375, 2006.

Mahowald, N., Jickells, T. D., Baker, A. R., Artaxo, P., BenitezNelson, C. R., Bergametti, G., Bond, T. C., Chen, Y., Cohen, D. D., Herut, B., Kubilay, N., Losno, R., Luo, C., Maenhaut, W., McGee, K. A., Okin, G. S., Siefert, R. L., and Tsukuda, S.: Global distribution of atmospheric phosphorus sources, concentrations and deposition rates, and anthropogenic impacts, Global Biogeochem. Cy., 22, GB4026, doi:10.1029/2008GB003240, 2008.

Mazzei, F., D’Alessandro, A., Lucarelli, F., Nava, S., Prati, P., Valli, G., and Vecchi, R.: Characterization of particulate matter sources in an urban environment, Sci. Total Environ., 401, 81-89, 2008.

Mbenguea, S., Allemana, L. Y., and Flamenta, P.: Size-distributed metallic elements in submicronic and ultrafine atmospheric particles from urban and industrial areas in northern France, Atmos. Res., 135-136, 35-47, 2014.

Mona, L., Amodeo, A., Pandolfi, M., and Pappalardo, G.: Saharan dust intrusions in the Mediterranean area: three years of Raman lidar measurements, J. Geophys. Res., 111, D16203, doi:10.1029/2005JD006569, 2006.

Negral, L., Moreno-Grau, S., Moreno, J., Querol, X., Viana, M. M., and Alastuey, A.: Natural and anthropogenic contributions to $\mathrm{PM}_{10}$ and $\mathrm{PM}_{2.5}$ in an urban area in the Western Mediterranean coast, Water Air Soil Pollut., 192, 227-238, 2008.

Ny, M. T. and Lee, B. K.: Size distribution of airborne particulate matter and associated metallic elements in an urban area of an industrial city in Korea, Aerosol Air Qual. Res., 11, 643-653, 2011.

Pant, P. and Harrison, R.: Critical review of receptor modelling for particulate matter: a case study of India, Atmos. Environ., 49, 1-12, 2012.

Pey, J., Querol, X., Alastuey, A., Forastiere, F., and Stafoggia, M.: African dust outbreaks over the Mediterranean Basin during 2001-2011: $\mathrm{PM}_{10}$ concentrations, phenomenology and trends, and its relation with synoptic and mesoscale meteorology, Atmos. Chem. Phys., 13, 1395-1410, doi:10.5194/acp-13-13952013, 2013. 
Pope III, C. A. and Dockery, D. W.: Health effects of fine particulate air pollution: lines that connect, J. Air Waste Manage., 56, 709_ $742,2006$.

Quiterio, S. L., Escaleira, V., Sousa, C., Maia, L., and Arbilla, G.: Metals in airborne particulate matter in downtown Rio de Janeiro, Brazil, Bull. Environ. Contam. Toxicol., 72, 916-922, doi:10.1007/s00128-004-0331-2, 2004.

Spagnuolo, V., Zampella, M., Giordano, S., and Adamo, P.: Cytological stress and element uptake in moss and lichen exposed in bags in urban area, Ecotox. Environ. Safe., 74, 1434-1443, 2011.

Trippetta, S., Caggiano, R., and Telesca, L.: Analysis of particulate matter in anthropized areas characterized by the presence of crude oil pre-treatment plants: the case study of the Agri Valley (Southern Italy), Atmos. Environ., 77, 105-116, 2013.

Trippetta, S., Caggiano, R., and Sabia, S.: PM $_{1}$ measurements at a site close to an oil/gas pre-treatment plant (Agri Valley - southern Italy): a preliminary study, Nat. Hazards Earth Syst. Sci., 14, 2337-2346, doi:10.5194/nhess-14-2337-2014, 2014.

Vallius, M., Lanki, T., Tiittanen, R., Koistinen, K., Ruuskanen, J., and Pekkanen, J.: Source apportionment of urban ambient $\mathrm{PM}_{2.5}$ in two successive measurement campaigns in Helsinki, Finland, Atmos. Environ., 37, 615-623, 2003.

Viana, M., Querol, X., Alastuey, A., Ballester, F., Llop, S., Esplugues, A., Fernandez-Patierd, R., García dos Santos, S., and Herce, M. D.: Characterising exposure to PM aerosols for an epidemiological study, Atmos. Environ., 42, 1552-1568, 2008.
Wang, Y.-F., Huang, K.-L., Li, C.-T., Mi, H.-H., Luo, J.-H., and Tsai, P.-J.: Emissions of fuel metals content from a diesel vehicle engine, Atmos. Environ., 37, 4637-4643, 2003.

WHO: Air Quality Guidelines for Europe, 2nd Edn., WHO Regional Publications, European Series No. 91, Copenhagen, 273 pp., 2001.

Wolterbeek, B.: Biomonitoring of trace element air pollution: principles, possibilities and perspectives, Environ. Pollut., 120, $11-$ $21,2002$.

Wolterbeek, H. T. and Bode, P.: Strategies in sampling and sample handling in the context of large-scale plant biomonitoring surveys of trace element air pollution, Sci. Total Environ., 176, 33 43, 1995.

Yatkin, S. and Bayram, A.: Elemental composition and sources of particulate matter in the ambient air of a Metropolitan City, Atmos. Res., 85, 126-139, 2007.

Yurukova, L. and Ganeva, A.: Active biomonitoring of atmospheric element deposition with Sphagnum species around a copper smelter in Bulgaria, J. App. Bot.-Angew. Bot., 71, 14-20, 1997.

Zunckel, M., Saizar, C., and Zarauz, J.: Rainwater composition in northeast Uruguay, Atmos. Environ., 37, 1601-1611, 2003. 